\title{
Key challenges for the fashion industry in tackling climate change
}

\author{
Matthew Hibberd, USI - Università Svizzera Italiana, Institute for Media and Journalism (IMeG), \\ matthew.hibberd@usi.ch
}

\begin{abstract}
The global rise in the earth's surface temperature in coming decades will bring with it increased instances of flooding, drought and volatile weather patterns. One of the main industries affected is fashion, which is responsible for some $5 \%$ of current global carbon emissions (Bauck, 2017). There is common acknowledgement that every stage in the production of garments for the fashion world creates pollution and emission problems: from sourcing and use of scarce water resources in the production of cotton, to farming processes in the production of leather, from the use of industrial dyes and synthetic textile fibres to the need for ships, planes and lorries to transport the final product globally. This article explores the main challenges facing the fashion industry from climate change. The main argument of this essay is that fashion has grown to be a key exemplar industry of global capitalism, often being associated with the positive and negatives excesses of globalisation. It is also therefore seen as one of the key industries responsible for climate change causing much reflection within the industry as to how this key issue should be tackled. On the plus side, the fashion industry can capitalize on its modern high-profile status to bring real attention to climate change issues through publicity and media attention. The global scale of clothing manufacturing and distribution, and the pollution it helps to create, has led many in the industry to seek ways to promote climate change initiatives in the industry. This aspiration, though, is a most difficult one in an industry with complex global production and distribution chains and one which is so embedded in modern consumer culture, often blamed for the worsening environment degradation worldwide.
\end{abstract}

\section{Keywords}

climate change, global warming, globalisation, modernity, post modernity

\section{Introduction}

Climate change is a major social issue facing the human race. Expert predictions relating to climate change are extremely bleak with some arguing that global temperatures are likely to rise by about $3^{\circ} \mathrm{C}$ by 2100 , ranging from $2^{\circ} \mathrm{C}$ to $5^{\circ} \mathrm{C}$ (Stern, 2006). The global rise in temperature in the coming decades will bring with it increased instances of flooding, drought and volatile weather patterns. This will have a significant impact on basic water supplies and food production especially if, as predicted, the world's population increases to around 11 billion people by 2050 . Climate change will impact on all countries, but current advice is that it will have a disproportionate effect on countries in rapid development from agricultural to industry-led economies (Hibberd, 2013b; 2014; 2016 and forthcoming). One of the main industries affected is fashion, which is responsible for some $5 \%$ of current global carbon emissions (Bauck, 2017). Every stage in the production of garments for the fashion world creates pollution and emission problems: from sourcing and use of scarce water resources in the production of cotton, to farming processes in the production of leather; from the use of industrial dyes and synthetic textile fibres to the need for ships, planes and lorries to transport the final product globally. And some issues offer a no-win solution to the industry, for example, in the choice of whether to use leather, cotton or synthetic materials as a main fabric in the garment-making production process.

The main aim of this article is to explore the main challenges facing the fashion industry from climate change. For this article, I define the fashion industry as the design, manufacturing, distribu- 
tion, marketing, retailing, advertising, and promotion of all types of apparel from the most expensive haute couture and designer fashions to ordinary everyday clothing (Britannia, 2017). The main argument of this essay is that fashion has grown to be a key exemplar industry of global capitalism, often being associated with the positive and negatives excesses of globalisation. It is also therefore seen as one of the key industries responsible for climate change causing much reflection within the industry as to how this key issue should be tackled. Fashion is often celebrated in the media and closely associated with the shiny postmodern world of international celebrity status, conspicuous consumption and global advertising campaigns. The downside to this are the dire work conditions many garment workers still face in parts of the developing world with the debilitating combination of low wages, long working hours and hot or cramped working conditions. Industrial injuries are also a daily risk for many workers. Many of these same arguments are being played out when it comes to climate change. On the plus side, the fashion industry can capitalize on its modern high-profile status to bring real attention to climate change issues through publicity and media attention. The global scale of clothing manufacturing and distribution, and the pollution it helps to create, has led many in the industry to seek ways to promote climate change initiatives in the industry. This aspiration, though, is a most difficult one in an industry with complex global production and distribution chains and one which is so embedded in modern consumer culture, often blamed for the worsening environment degradation worldwide.

This article will be split into five parts including this introduction and the conclusion. The next part of the essay will explore the relationship between global capitalism and fashion. The third section introduces the challenging issue of climate change for those working in clothing and textiles. In the fourth section, we examine broad attempts of using public campaigns, which include fashion involvement, to focus attention on climate change with particular attention paid to two popular British climate change initiatives. This paper is based on interviews with climate change experts and those working within the campaigning industry including 10:10 and the WWF's Earth Hour campaign, the two initiatives examined here.

\section{Fashion, consumption and global capitalism}

The development of the fashion industry is intimately tied in to the wider economic, political and cultural transformations of the past two and a half centuries, namely the rise of nationalism. The key features of European nationalism are a unitary political authority (the state) and a national culture. Nationhood has also favoured those societies that have evolved similar cultural habits through the slow sedimentation of multi-culturalism and by the emergence of a single political authority (Giddens, 1990, pp. 50-58). As Kate Nelson Best outlines in her history of fashion journalism, fashion has always been laced with nationalism ever since Louis IV. The rise of European nationalism in the late $18^{\text {th }}$ Century constitutes a key period when the processes of nation-building along with industrialisation and urbanisation brought about the reconfiguration of social classes and traditional economic ties (Best, 2017). The emergence of new urbanized social classes and the growth of educational systems and cultural institutions also brought about changes in how societies viewed clothing. In this sense the fashion industry remains tied to national boundaries and cultures, which often play out in ritual clothing events being tied to cities and national occasions. So at one level the relationship between fashion and climate change, the most global of challenges, is mediated through national contexts, especially in the mass media, and one key way for the industry to make the climate change issue visible is via the national consciousness.

But at the same time theorists label fashion as a key player in promoting post- 
modern values not modernist ideas of nationalism. Indeed, if the nation-state is a political configuration of modernity, the advent of a postmodern condition has also warranted an urgent rethink on how citizenship and consumerism can be hypothesised outwith the nation-state, especially in relation to fashion. Anthony Giddens argues that in the period of modernity defined broadly as the age of industrial capitalism - the concept of time-space distanciation has occurred: the separation of time and space through the intensification of worldwide social relations. Social relationships have to an extent become disembedded and disconnected from traditional face-to-face interactions. Instead, social relationships via communications and the mass media have become reembedded across different social places and physical places (Giddens, 1990, p. 3). The jump to a postmodern condition has occurred through the acceleration in the globalising and unifying tendencies of capitalism. The rapid expansion of global capital accumulation, aided by instant media and communication networks, and a supply of cheap, international labour, has resulted in a further distribution of social relationships across time and space. This has created conditions in which a new social order can emerge. The postmodernist claim is that this new economic, social and technological revolution has impacted on how culture is made and remade. Some theorists have emphasised the increasing economic and political importance of multinational companies and special interest movements, effectively bypassing the nation-state (Melucci, 1990, p. 335; Schlesinger, 1992, p. 13).

The fashion industry is not only linked to modernist concepts such as nationalism but increasingly to ideas of postmodernity. The onset of the postmodern condition through the rapid intensification of global economic and social relationships, mass migration and the development of ICTs and digital media, has given rise to the concept of globalisation. Social relations, in part, have become disconnected from traditional face-to-face interactions and are commonly conducted through social media or other digital forms. As Giddens argues, 'social relations through communications and the media have become re-embedded in various social places and physical spaces' (Giddens, 1990, p. 3). The rise of the western postmodern state has been facilitated by monopoly capitalism and international trading and migration. Concentration of wealth in many countries has created a ready supply of cheap labour, leading to millions seeking work and new lives in other countries, breaking the traditional boundaries of face-to-face relationships. New global diasporas have emerged resulting in the redefinition of cultures including, it is often argued, new global cultures including fashion. The postmodernist makes the claim that multi-national companies and global NGOs have assumed as much importance as most nation-states (Melucci, 1990:, p. 335; Schlesinger, 1992:, p. 13).

The development of giant fashion companies highlights the congruence of financial muscle with cultural hegemony. Global fashion businesses are driven by readily identified brand names. No matter whether a brand is expensive and available world-wide or modestly priced and on sale only locally, it will embody a guarantee of authenticity. That is, it will be what it appears to be and its origins are known, at least as regards the identity of the company producing it. Associated with a brand's authenticity is its consistency, the fact that it can be depended on to deliver a certain quality each time it is bought. A global brand such as Zara can be relied upon to provide a particular range and quality of clothing around the world. The element of trust, born of experience that consumers feel towards a certain brand simplifies the making of future choices for them from among the plethora on offer. Thus it makes possible a saving of time and effort through a reduction of perceived risk. In this respect, the appeal of a brand to a consumer can be said to be rational or functional. But it is also emotional or experiential. As with anything that communicates, there is also a connotative or cultural dimension to consider, i.e. those less easily defined associations which are triggered 
in people's values. Some of these effects will be culturally determined, while others will be the result of individual personal experience. The global appeal of fashion brands makes the industry a perfect forum for climate change awareness and promotion. Few global industries have the international recognition like fashion. The argument therefore is that industry-wide initiatives, harnessed by the global brands, could place climate change at the centre of social marketing campaigns.

And, yet, the rise of global fashion brands and multinational conglomerates have met with increasing resistance from the disparate collection of groups opposed to globalisation, most famously exemplified perhaps by Naomi Klein and the No Logo lobby, but increasingly occupied today by environmental groups. Those within and outside the fashion industry have long been aware of resistance or struggles relating to clothing, environmentalism and nationality. The Swadeshi movement in India until Independence in 1948 used clothing as a key symbol of Indian resistance and struggle to British rule. The aim to promote indigenous Indian cotton production and boycott dominant British imports of cotton and garments was also given a strong sustainability agenda by Mohandas K. Gandhi. British-made clothing would be burnt at gatherings, with Indians exhorted to wear Indian-made clothes or make their own. What Gandhi and others preached is what we would today call localism, which is a key idea for many supporting sustainability or environmentalism (Yerra, 2014).

And in other areas, too, the concept of resistance has even played a prominent role in giving the fashion industry increased energy and drive. For example, much of the energy driving the reemerging British fashion industry in the 1960s and 1970s was premised on protest and resistance against the prevailing social order of the day. Clothing was a key part of identity among those groups rebelling against society: mods, rockers and, especially, the punk rock movement of the 1970s. In Dick Hebdige's classic text, Subculture: The Meaning of Style, he argues that:

\begin{abstract}
The subcultures with which we have been dealing share a common feature apart from the fact that they are all predominantly working class. They are, as we have seen, cultures of conspicuous consumption - even when, as with the skinheads and the punks, certain types of consumption are conspicuously refused - and it is through the distinctive rituals of consumption, through style, that the subculture at once reveals its "secret" identity and communicates its forbidden meanings. It is basically the way in which commodities are used in subculture which marks the subculture off from more orthodox cultural formations. (Hebdige, 1979, pp. 102-103)
\end{abstract}

In essence, therefore, the buying and consumption of clothing, in recent times, has also occurred through the myriad of subcultures within societies, each with its own sets of norms, rituals and values that distinguish it from more orthodox cultural formations. In that sense, any alignment of the global fashion industry towards climate change promotion must also understand the complexities of the modern consumer and their sets of values and norms that might often fall at odds with those of wider society. It is no accident, for example, that one of the leading emerging clothing designers in punk rock London, Dame Vivienne Westwood, identified with the political agendas of prominent subcultures, including environmentalism, long before those agendas became accepted by wider society. And it is the sheer heterogeneity of modern fashion styles and tastes as well as of contemporary consumers that may help us understand why it has been so difficult for the fashion industry to unite fully behind climate change in recent years, as we discuss in the next section.

\section{Climate change and global fashion}

As stated earlier in this essay, the fashion industry is often linked to the various tendencies of global capitalism. According to different political standpoints, fashion can either be seen - positively - as promoting new forms of liberal individual or collec- 
tive power in contemporary societies or more negatively - as instrumental in reinforcing economic and social disparities such as poverty and human rights violations in the developing world through employment contracts. And the latter point is important because climate change is also becoming increasingly associated with global economic and social inequalities and UN Millennium Goals initiative. One argument often cited is that that developing nations will be disproportionately affected by climate change and that a fundamental link exists between environmental damage and poverty. This argument, put forward by the likes of former British Prime Minister, Gordon Brown, sees climate change as an issue about justice as well as economic development (Brown, 2008). Linking poverty alleviation to climate change has placed many industries, including fashion, under the spotlight of criticism placing them on the defensive. There is a strong body of opinion, especially among development aid groups, NGOs and charities that many fashion houses outsource production of their clothing to developing nations for purely economic reasons, paying little more than subsidence wages with workers often sub-contracted to smaller companies that offer horrendous working conditions and employment environment. The argument goes that lip service is often paid to the idea of ensuring all workers earn a proper living wage or work in more humane conditions.

One example of this, though not linked directly to climate change, was the response after the Savar Building collapse in Bangladesh in 2013 that saw more than 1000 textile workers die. This was despite calls immediately prior to the disaster that the building in question should be evacuated as unsafe, a call that went unheeded by the building owner under pressure to let companies continue producing cheap clothes. Because the building housed many sub-contractors, many of the main clothing houses in the west, including the likes of Benetton and Walmart, were unaware that their clothes were being produced on site. Some companies even denied claims until clothing labels were pulled from the rubble of the building demonstrating that leading brand names were having clothes produced in the building at the time of collapse (Rezwanul, Waliur, \& Gul, 2017). Five years on, support for the victims of the Savar Building collapse has been, at best, patchy. Some companies or national associations, such as Benetton, have made payments to support injured workers or bereaved families of workers or instituted codes of conduct for members producing clothing in the developing world to ensure that any sub-contracting of work does not lead to deterioration in worker employment rights. Other companies, though, have been less forthcoming in support. The main accusation today is that the fashion industry has been unable to work in unison to help workers in one of the poorest countries in the world (Rezwanul, Waliur, \& Gul, 2017. So if support is less that complete in such a case directly associating the industry with a building collapse, what chance, if any, is there of concerted industrial support for such countries in the aftermath of some climate change-related disaster, such as flooding or drought? And at this point in time major support is lacking in this area. It can be argued that many industries, not only fashion, need to greatly improve their work with local and national stakeholders in becoming more active with climate change adaptation.

This lack of any concerted or unified response to the Savar disaster might not indicate any lack of willingness for many in the industry to act for the mitigation of climate change and involvement in public awareness campaigns. And, indeed, some fashion companies and prominent individuals have for decades been looking for ways to make the whole garment-making process more environmentally friendly and to mitigate the process of climate change. Initiatives are abound, locally, nationally and internationally, of environmentally-conscious designers, producers, distributors and department stores, initiating ways to make the industry greener. This can range from the recycling of fabric and textile materials, including plastics, or 
the use of sustainable materials in the production of clothes, to encouraging consumers to lower temperatures on washing machines. Low temperature washes are less harmful to the environment than high temperature washes. And the clothes tend to last longer too. One prominent campaigner, as cited already in this essay, is Dame Vivienne Westwood. In 2014, in an interview with the Guardian, Westwood argued:

"Do I feel guilty about all the consumption that the fashion world promotes? Well, I can answer that by saying that I am now trying to make my own business more efficient and self-sustaining. This also means trying to make everybody who works in it happy, if I can." ... "What I want people to be able to do is to buy well, by first choosing well and then making it last. And I also believe that if everyone wore just a few beautiful things, there would not be such a climate change problem," she said. "In my view it is worse for someone to come out of a shop with an armful of new T-shirts made in a sweatshop, than it is for a rich lady to buy one beautiful dress."

She adds:

"The designer aims," she said, "to work on areas with achievable goals and she chronicles her activities on the website Climate Revolution." She sees the western economy as "intertwined" with ecological danger, "like two snakes." "I can't speak for the views of other fashion designers. Some of them don't seem to be interested in anything but fashion and they even go on holiday with designers and magazine editors, but they have all been very supportive of me." (Thorpe, 2014)

Although by no means can Westwood be giving a ringing endorsement to the fashion industry here, more and more fashion companies have embedded sustainability into corporate identity schemes, corporate (good) governance, branding, marketing, stakeholder relations, ethical investments and other ways in recent years. These efforts, such as by Professor Helen Storey, British artist, designer and academic, have become more concerted and coordinated, producing positive results while raising levels of encouragement for further action.

There is also evidence that the industry was broadly supportive of international attempts to limit the impact of climate change, most notably through the Paris climate change agreement in December 2015, which many sustainability officers working for the big fashion houses welcomed as a key measure to support fashion companies reduce their carbon footprint. However, there were also those in the industry worried by the additional costs to businesses associated with the agreement and new climate change regulations and who argued that this might deter a more concerted favourable industry response (Abnett, 2015). And the argument of this essay is that industry-wide efforts with climate change have tended to lack comprehensive strategies - see discussion above with many within the industry recognizing that climate change can be better tackled effectively through broader civil society initiatives.

\section{Fashion industry and climate change campaigns}

Thus the latter point highlights the fact that for many working in the fashion industry, the only comprehensive way to tackle climate change is to align the industry to broader political and social initiatives such as international climate change agreements, government initiatives to meet lower carbon emission targets and environmental campaigns run by NGOs. There is also support for the greater use of educational and promotional activity is required if global citizens are to be persuaded to change their lifestyles and promote more sustainable forms of living. One such area where the climate change campaigns and programmes are being increasingly encouraged is in Corporate Social Responsibility initiatives (CSR). Jones, Bowd and Tench (2005) define CSR as 
Corporations being held accountable by explicit or inferred social contract with internal and external stakeholders, obeying the laws and regulations of government and operating in an ethical manner which exceeds statutory requirements. This "ethical manner" is placed at the core of the entity's strategy, exemplified by proactive community involvement, philanthropy, corporate governance, corporate citizenship, addressing of social issues, a commitment to the quality of its products and services, human rights, health, safety and the environment and its staff... While all the time this accountability should ensure a continual emphasis on generating growth, revenue and profit for the corporate entity and its shareholders/owners, facilitating this process either directly or through positive effects on the entity's intangible assets, such as brands and reputation. (p. 4)

Much CSR work does indeed have an ethical dimension where businesses go beyond basic economic and legal requirements to do what it sees is 'just' and 'fair', exceeding public expectations of normal business practice. In ideal circumstances, businesses become exemplary corporate citizens working with public and private sectors alike to further community projects or government policies, thereby providing social value-added outputs. CSR, at best, recognizes that environmental degradation and pollution are not inevitable and that opportunities for community consultation and involvement should be maximized. But historical and contemporary practice demonstrates that businesses can fall well short of basic CSR requirements, especially in their advertising and marketing campaigns dealing with environmental claims. Promoting 'green' issues is merely given lip service in the pursuance of greater corporate profits or seen as 'window dressing', as author and advertising executive John Grant put it: "You can't put a lettuce in the window of a butcher's shop and declare you are turning vegetarian" (Quoted in Aitken, 2007. Advertising greenwash is highlighting the growth of marketing spin rather than providing serious credence to corporate ecological credentials. And, as such, it can also form a pernicious barrier to effective corporate behavioural change.

There have however been increasing attempts among companies, including fashion, to adopt green "values" in branding and marketing campaigns. From food and drink producers to supermarket chains, from energy companies to fashion-chains, companies are being asked by social media, NGOs and public about their green credentials. CSR is being increasingly utilised in green debates and campaigns adding, arguably, environmentally-friendly and sustainability as value-added dimensions to campaigns (McGarvey, 2007). The number of green campaigns has mushroomed in the past three decades in line with the growth of CSR and, increasingly, corporate groups are working with leading NGOs, media outlets and other campaign groups on climate change issues. We will now look at two British cases, both of which have received widespread support of the fashion industry. As part of research in to climate change, we spoke to representatives of the 10:10 campaign, London, and the Earth Hour in Scotland, UK, examining instances of fashion involvement.

\section{The 10:10 campaign}

The 10:10 carbon emission reduction campaign which, although still less than a decade old, has suggested a number of potentially fruitful pathways for involving ordinary people and organisations at all levels in climate-related behavioural changes. 10:10 is a brainchild of the British film maker, Franny Armstrong, in her response to overwhelming public responses to her climate documentary, The Age of Stupid. Its central idea is to encourage and provide the necessary facilities for individ-

1 Research for these case-studies were carried out as part of a project funded by the British Council in New Delhi, India. I would like to thank the Council for its financial support and also my two co-investigators, Alka Tomar and Dr An Duc Nguyen, for their help and support in conducting the research project. 
uals and organisations to cut their carbon emission by $10 \%$ in one year, and then another $10 \%$ in the following year, and so on until it reaches the lowest possible level. Those who sign up are committed to addressing this compound year-on-year $10 \%$ challenge and are given practical advice to do so.

By some quantitative measures, the campaign had an early considerable success. Within six months of its launch in September 2009, it had drawn nearly 60000 sign-ups (including not only individuals but also thousands of organisations such as schools, businesses and local councils) and raised a modest but impressive $£ 400000$ budget from private donors, trusts and funds. One of the earliest supporters of the campaign was Dame Vivienne Westwood. Why such large and high-profile followings within a relatively short time? The answer to this question might require a long list of factors - such as the motivation and creativity of its young team, its diverse and effective use of various media outlets and platforms (including a formal partnership with the Guardian from the very beginning), its working tenets and principles and so on. But perhaps the underlining reason lies in the core philosophy of the 10:10 campaign: everyone can cut their carbon emissions as long as it is tied to their daily life in a practical way. Instead of following the usual method of communicating and educating people of the potentially dramatic but still distant and abstract impact of global warming, 10:10 takes a pragmatic stance, endeavouring to drive people from the "what's the point in me in this big thing?" towards the "Yes, I can do it" or "Yes, it is beneficial for me" mindset. As its former director, Eugenie Harvey, explained:

My mantra is that... you have to meet people where they are, not where you think they should be... Effective CC engagement is about recognising the reality of people's lives and speaking to that reality... People have busy, complex lives and it's not easy. So it's not realistic to expect them to radically change or reengineer those lives to the sort of life styles we know are necessary to start to reduce car- bon emissions... One of the mistakes climate campaigns have made over the years has been to think that people would be engaged by doom stage scenarios... The truth is that we... a lot of people are not going to be engaged by being told everything is terrible and the world is coming to an end and it's all our fault. You need to align all your activities to some part of their daily life. Take them through their daily channels and use the narrative and language... which chime with them.

(The other point to engage the less engaged is that) we have to be realistic about the ability of people to change and the time scale that people can change - and that is the good thing about this campaign. Perfect is the enemy of good and perhaps one of the mistakes that have been made, quite likely unwittingly, is to ask people to change their behaviours to such an extent that they become the kind of perfect low-consuming individuals. And I think that it is not realistic and should be sacrificed for being good - lots of people being good rather than a small number of people being perfect. (Harvey, personal interview with An Duc Nguyen and Matthew Hibberd)

In practice, this philosophy translates into promoting and encouraging people and organisations to gradually change the way they live or operate so that they can cut carbon emissions at the same time as saving money (through, for instance, efficient energy or fuel or water use), improving their health (through fruit and vegetable diet), feeling happier and more worthy, and so on. The key objective, according to the campaign's content manager, Malachi Chadwick, is to create a narrative that is "sufficiently catchy and sufficiently inclusive so that people... get interested in it... and do something about... their emission". At a more operational level, this includes practical "down to earth" simple instructions that people can print out from its website and stick on their wall or fridge - such as

, turning down your thermometer turning off radiators in hallways applying for a grant to insulate your loft and walls 
changing light bulbs

buying and selling second-hand things

only running full dishwashers and washing machines.

One of the earliest examples of fashion-related initiatives organised through 10:10 was promoting second-hand fashion. The Guardian's Patrick Barkham's highlighted his own attempts to cut down on new clothes purchasing:

I have suits for work, shorts for running, boots for climbing mountains, tracksuit bottoms for vegetating, flip-flops for the beach, party shirts for partying and reassuring knitwear for meeting great aunts. I have five pairs of gloves, four hats and two eye-masks. I have most bases, and all extremities, more than covered. Like most people, I find shopping in our soulless malls and tatty clone high streets an increasingly tedious chore. Clothes, however, remain the exception. Retail therapy still works for me in the likes of Zara and H\&M, where you can buy a whole fresh look for a couple of hundred quid. As a shy teenager, clothes made me feel better about my crap body; a new shirt still gives me a lift for at least three wears. After that, the shirt is still fine but the buzz wears off. This is a familiar consumerist addiction. But I have almost as many years behind me as shirts; I should grow out of such cheap, confidence-boosting tricks. Giving up buying new clothes has a "hair shirt element which is not appealing to most people," says Chris Goodall, author of Ten Technologies to Save the Planet. "There is something hard-wired within us that makes us desire things even when we don't need them. The idea we have got to consume less is incompatible with the culture of the moment." Rather than go cold turkey, Goodall recommends "I wean myself off this clothes addiction by continuing to buy secondhand." (Barkham, December 31, 2009)

Another prominent campaign by 10:10, and also fashion linked, was holding sewing masterclasses teaching young people to repair clothes rather than buy new ones. This initiative was led by Sophie Barclay:

There are a number of things that you can do to keep your clothes in good condition for longer. And when they do start falling apart, there's Sophie's mending masterclass with advice on how to repair them ... Sophie Barclay has sewn many a pocket and patched a fair few pairs of jeans in her time. As a freelance costume designer and maker, she has become her friends' first choice when their clothes are in need of a quick fix. But she assures me that there's nothing too sophisticated going on "Anyone can do this - it's fun and it's easy. I do it in front of the TV!" $(10: 10,2018)$

What, then, has been the overall impact of 10:10 on actual behavioural changes on its participants? This, unfortunately, remains to be assessed. 10:10 has not been able to quantify its real impact, since it does not use any mandatory reporting system in which participants provide feedback on their action year. However, voluntary reports from participants show at least a good deal of anecdotal evidence of encouraging and sometimes very impressive changes.

\section{WWF Earth Hour}

One of the most popular environmental events each year that attracts many fashion companies is the WWF Earth Hour Initiative. Every year fashion events are organised around this occasion. The Earth Hour is a global event organized by World Wildlife Fund (WWF) and is held annually in late March (this year at March 24, 2018). The key requirement of Earth Hour consists of asking households and businesses to turn off their non-essential lights or appliances for one hour to raise awareness for climate change. Earth Hour was started in Australia in 2007, when more than two million residents of Sydney participated by turning off all non-essential lighting and other electrical appliances. Many other cities and countries, including the UK (we study the Scottish initiative for this research) then adopted the event in 2008. WWF argue on their website that

Earth Hour is a simple idea that's quickly turned into a global phenomenon. Hundreds of millions of people turning off their lights 
for one hour, on the same night, all across the planet. But it's not to save an hour's electricity. It's something much bigger. WWF's Earth Hour is about people coming together to put the focus on this brilliant world we all share and how we need to protect it. Not just for an hour a year, but every day. Because a healthy planet isn't just good for polar bears or tropical tree frogs. It's essential for us all. It's easy to forget how much we depend on it for food, fuel, water, fresh air... And the truth is our modern lifestyles have been taking a toll on our planet. WWF already tackles a lot of the environmental impacts - like deforestation, endangered species, and the impacts of climate change. But Earth Hour is a chance for everyone to say they'll do their bit. And that's never been more vital. And, Earth Hour is a celebration. It's always a night to remember whether it's a special candlelit evening at home with friends or family, or a night out on the town, or watching the spectacular global switch-offs from landmarks like the Eiffel Tower, the Pyramids of Giza, Times Square, Sydney Opera House ... (WWF, 2018)

The first key point to make about WWF Scotland is its close relationship to British and international equivalents on the one hand, but the importance of the Scottish political agenda on the other hand. As their Scottish communication officer argues:

Some of our efforts are driven by a result of what we do as part of WWF UK, but the very fact that we have an office here in Scotland is because we're meant to look at different ways of doing things, we have our own parliament, culture, you know, so as many institutions in Scotland we will operate and engage in a slightly different way, than say, we would do it at UK level.

The Scottish context therefore guides what WWF Scotland does. An important element to their operations is to lobby the Scotland Government to maintain pressure and momentum on regulatory concerns. The Scottish Climate Act of 2008 has sent ambitious targets for Scotland to reduce its carbon footprint by 2020 . As WWF's communication officer argued:
I would say probably the main reason for us working on Earth Hour at all is because we know that after the Scottish Climate Change Act we still need to keep up the pressure and the momentum to make sure that Act is delivered. So you can have all the best laws in the world, the best targets in the world, but if there's nobody there that keeps pushing them to be delivered then forget it. So I'll be quite blatant for working on this, in Scotland anyway, is because we see the opportunities to keep the pressure, the momentum and the understanding of climate change on the agenda. Whether it's in the media, political, business, whatever it was, we know that it offers a great vehicle to do that. That has meant we have engaged quite heavily politically in Earth Hour, more so than perhaps in other countries and certainly more so than they've done at the UK level because we've wanted to show politicians that people care.

The other key reason for Earth Hour was to raise public awareness and allow participants to take concrete measures lowering their carbon footprint for one hour and then in subsequent weeks and months:

The challenge has changed every year, so the first year it was just a case of putting it on the map, what was really nice to have was the fact that they had done it so well in Sydney, so we had something to show, there was something visual, there was a buzz. The interesting thing was that even though we didn't do it here that year, different people did participate in the Earth Hour round the world because they heard about it and got excited by it. Some have taken part in Earth Hour on the day, you know, by switching off their building, some of them have said “I don't have a building to switch off, I'll do something else." The backbone for our work in Scotland has actually been our local authorities and they give us an opportunity to communicate with communities in Scotland we wouldn't otherwise get to because either we can't reach them with our advertising or we've got no existing connection with them. One of the most powerful alliances has been with our local authorities.

In 2018 this includes working with Scotland's biggest city council, Glasgow, to 
organise a range of initiatives around the Earth Hour day on $24^{\text {th }}$ March. The focus of events in 2018 included highlighting the efforts of the fashion industry to tackle climate change. Among the events organised by WWF and Glasgow Council were:

"Waste, not Want" - sustainable fashion brand, KPCouturé, will be aiming to encourage conversations around sustainability in the fashion industry as well as showcasing their products including clothing and accessories from donated scrap fabric and jewellery from plastic building waste processed in their on-site plastic processing centre.

And

"Rags to Riches" - showcasing articles made from everyday throwaway materials and lantern making. (Glasgow Council, 2018)

Another major partner in 2016 was the $H \& M$ clothing group that used the WWF Earth Hour event to launch environmentally friendly clothing ranges:

All the garments are certified organic cotton, following strict environmental and social criteria. Designs are recognizable by their realistic prints of iconic species at risk. The collection will be available in H\&M stores worldwide and online starting 29th of September. $10 \%$ of the sales price of the collection will support WWF's work in conserving endangered species. The Kids collection features animal prints of species such as the tiger, panda, snow leopard, polar bear and the finless porpoise, that are facing many threats including habitat loss, water pollution and the impact of climate change. The collection mainly consists of comfortable and easy to wear organic cotton-based items such as long sleeve sweaters, T-shirts, dresses, tights, trousers and pyjamas for babies and kids between 1,5 and 14 years old. The aim of the collection is to inspire H\&M's customers to care for the planet as well as to highlight our transformational partnership, which focuses on water stewardship and climate action, as well as strategic dialogue related to both H\&M's and the fashion industry's broader sustainability challenges. (WWF, 2016)
Arguably, as argued above, the quantitative effectiveness of such campaigns is unknown and public response in terms of behavioural change can often limited. There are arguably multiple reasons for why people remain resistant to altering lifestyles to in the face of apocalyptic warnings on climate change, but attempts such as the WWF's Earth Hour or the 10:10 initiative demonstrate how individuals can feel part of a larger movement and undertake practical solutions to help cut carbon footprints.

\section{Conclusion}

During the recent COP 24 Summit on Climate Change in Poland (November-December 2018), a new fashion-related initiative was launched called the Fashion Industry Charter for Climate Action. The initiative contains 16 pledges with the broad aims of reducing greenhouse gas emissions in the fashion industry and encouraging policy changes to help combat climate change. While such an initiative is welcome, some have pointed to past failures of the industry to unify behind green issues. As the journalist Victoria Moss argues:

The current predicament of the fashion industry makes me feel uneasy, partly because I am culpable for being part of a culture that pushes the new in and must-haves, but also because the sea of bad news surrounding the worst practices of the industry is not new: we know that child refugees are being drafted in to work in garment production in Turkey; that fast fashion factories in this country have been paying its workers far less than the minimum wage; that 1134 garment workers died when the Rana Plaza factory in Bangladesh collapsed on top of them; that farmers in India are ending their lives because they are so in debt to the companies which buy their cotton, but also trap them into expensive deals to purchase GM seeds and fertilisers; that in Prato, Chinese immigrants work at night in basements ensuring luxury labels a "Made in Italy" cache. Not to mention the burning of old stock and unused fabrics, the catastrophe 
of over-production and polluting ... but still we want more. (2018)

The main aim of this article has been to explore the main challenges facing the fashion industry from climate change. The main argument of this essay was that fashion has grown to be a major industry, often being associated with the key excesses of globalisation. Fashion is often identified as one of the key industries responsible for climate change and other problems identified with global capitalism, such as poverty. Fashion has a major part to play in climate change initiatives and can attract large-scale publicity. Fashion is often celebrated in the media and generates publicity across the world although little of this exposure ever relates, arguably, to climate change or UN Millennium Goal initiatives. While there are clothing companies and key individuals working to cut their own emissions and promote climate change and international initiatives (Abnett, 2015), this article has argued that the fashion industry as a whole has some way to go to promote concerted efforts in tacking one of the major social and political issues of its day. Previous examples show the difficulties the industry has in uniting in adverse times, such as demonstrated by the Savar building collapse in 2013. Also, the sheer scale of the industry and the very heterogeneous sets of consumers it serves, means that the industry is consistently servicing orthodox and sub cultures, disparate groups, which again may well be difficult to unite around fashion-related themes alone. This article has rather illustrated two climate change campaigns promoted through civil society that have been able to encourage a range of fashion houses to promote the climate change agenda.

\section{References}

Abnett, K. (December 16, 2015). What the COP21 climate agreement means for fashion, published in Business of Fashion. Retrieved from https:// www.businessoffashion.com/articles/ intelligence/what-the-cop21-climateagreement-means-for-fashion.

Advertising Standards Authority (ASA) (2008). Annual Report 2007. Retrieved from http://www.asa.org.uk/asa/newsnews/ 2008/ASA+Annual+Report+2007.htm. Last accessed May 23, 2008.

Aitken, L (November 19, 2007). 'Wiping Out Greenwash'. The Guardian. Retrieved from https://www.theguardian.com/ media/2007/nov/19/mondaymediasection.climatechange . Allan, S. (1999) News Culture. Buckingham: Open University Press.

Allan, S., Adam, B., \& Carter, C. (2000). (Eds.), Environmental Risks and the Media. London and New York: Routledge.

Anderson, A. (1997). Media, culture and the environment. London: University College Press.

Antilla, L. (2005). Climate of scepticism: US newspaper coverage of the science of climate change. Global Environmental Change, 15, 338-352.

Barkham, P. (December 31, 2009). 10:10 fashion: Can I give up buying clothes for a year?. The Guardian. Retrieved from https://www.theguardian.com/environment/2009/dec/31/10-10-fashion-clothes

Bauck, W. (September 22, 2017). The fashion industry emits as much greenhouse gas as all of Russia. Designers, CEOs and a data scientist weigh in on what it will take to change that. Fashionista. Retrieved from https://fashionista.com/2017/09/fashion-industry-greenhouse-gasclimate-change-sustainability.

Beck, U. (1992). Risk Society: Towards a New Modernity. London: SAGE.

Bell, A. (1994). Media (mis)communication on the science of climate change. Public Understanding of Science, 3(3), 259-275. doi:10.1088/0963-6625/3/3/002

Best, K. N. (2017). History of fashion journalism. Kindle Edition. London: Bloomsbury

Boykoff, M.T. (2008). Media and scientific communication: a case of climate change', in Liverman, D. G. E., Pereira, C. P. G. and Marker, B. (Eds), Communicating Environmental Geoscience. Geological Society, London, Special Publications, 305, 11-18. 
British Film Institute (2005). Britain's greatest contribution to cinema? www.screenonline.org.uk/film/id/446186/

Brown, G (2008). Speech to the UN General Assembly. October.

Brown, P. (1996). Global Warming: Can Civilization Survive? London: Blandford.

Bucchi, M. (1998). Science and the Media: Alternative Routes in Scientific Communication. London: Routledge.

Burgess, J., Harrison, C. and Maiteny, P. (1991). 'Contested Meanings: The Consumption of News about Nature Conservation', $\mathrm{Me}$ dia, Culture and Society 13(4): 499-519.

Carvalho, A. (2005). 'Representing the Politics of the Greenhouse Effect: Discursive Strategies in the British Media', Critical Discourse Studies 2(1): 1-29.

Carvalho, A (2007). 'Ideological cultures and media discourses on scientific knowledge: re-reading news on climate change', $\mathrm{Pub}$ lic Understanding of Science, 16 (2007) 223-243.

Corbett, J. and Durfee, J. (2004). 'Testing Public (Un)Certainty of Science: Media Representations of Global Warming', Science Communication 26(2): 129-51.

Doyle, J. (2007). 'Picturing the Clima(c)tic: Greenpeace and the representational politics of climate change'. Science as Culture 16 (2), 129-150

Dryzek, J. (1997). The Politics of the Earth: Environmental Discourses. Oxford: Oxford University Press.

Edmond, G. and Mercer, D. (1999). 'Creating (Public) Science in the Noah's Ark Case', Public Understanding of Science 8(4): 317-43.

Ereaut, G. and Segnit, N. (2006). Warm Words: how are we telling the climate story and can we tell it better? London: Institute for Public Policy Research (IPPR).

Futerra (2008). Greenwash Guide. Available at: http://www.futerra.co.uk/services/ greenwash-guide. Last accessed $23^{\text {rd }}$ May 2008.

Gamson, W. (1999). 'Beyond the Science-Versus-Advocacy Distinction', Contemporary Sociology 28(1): 23-6.

Gamson, W. and Modigliani, A. (1989). 'Media Discourse and Public Opinion on Nuclear Power: A Constructionist Approach', American Journal of Sociology 95(1): 1-37.
Garvie, J. (2008). The Ethics of Climate Change. Right and Wrong in a warming World. London: Continuum.

Gellner, E. (1997). Nationalism. London: Weidenfeld \& Nicolson.

Giddens, A. (1991). Modernity and Self-Identity: Self and Society in the Late Modern Age. Stanford, CA: Stanford University Press.

Giddens, A. (2009). The Politics of Climate Change. Cambridge: Polity.

Gray, J. (1995). Isaiah Berlin. London: Harper Collins.

Gregory, J. and Miller, S. (1998). Science in Public: Communication, Culture and Credibility. New York and London: Plenum Trade.

Hajer, M. (1995). The Politics of Environmental Discourse: Ecological Modernization and the Policy Process. Oxford: Clarendon Press.

Hansen, A. (1994). 'Journalistic Practices and Science Reporting in the British Press', Public Understanding of Science 3: 111-34.

Hebdige, Dick (1979). Subculture: The Meaning of Style. London: Methuen.

Hibberd, M. and Nguyen. A. (2013a). 'Communicating Climate Change: Findings from a Reception Study', in International Journal of Media and Cultural Politics, 9.1.

Hibberd, M. and Nguyen. A. (2013b). 'Communicating Climate Change: Introduction', in International Journal of Media and Cultural Politics, 9.1.

Hibberd, M. and Buchanan., M. (2014). 'Communicating Crises: An Asian Case Study', in Gili, Hibberd and Sorice (ed) Sociologia e politiche sociali.

Hibberd, M. and Tomar. A., (2016). Climate Action, Youth Voices. Delhi: CEC.

Hibberd, M. (2019, forthcoming). Communicating Climate Change and Public Engagement: Adaptation and Mitigation. Kolkata: Setu Prakashani .

Hulme, M. (2009). Why We Disagree about Climate Change. Understanding Controversy, Inaction and Opportunity. Cambridge: Cambridge University Press.

Intergovernmental Panel on Climate Change (IPCC) (2001). Climate Change 2001: The Scientific Basis. Cambridge: Cambridge University Press.

Intergovernmental Panel on Climate Change (IPCC) (2007). Climate Change 2007: 
The Physical Science Basis. Cambridge:

Cambridge University Press.

Irwin, A. (1995). Citizen Science: A Study of

People, Expertise and Sustainable Development. London: Routledge.

Izod, KJ, Kilborn, R and Hibberd, M. (Eds) (2000). From Grierson to the Docu-Soap:

Breaking the Boundaries. Luton: University of Luton Press.

Jameson, F. (1994). 'Postmodernism and the Market', in S. Zizek (ed.) Mapping Ideology, pp. 278-95. London: Verso.

Jeffries, S. (2009). 'If you're not fighting climate change or improving the world, you're wasting your life. Stuart Jeffries meets the creator of 10:10 and director of The Age of Stupid', Guardian, 1 September.

Jones, Bowd and Tench (2005). Corporate Governance: the Realities of Corporate Social Irresponsibility. Paper presented to CIPR Conference. Paper available at: http:// www.cpcr.org.uk/papers/ccgr/ jonesboydtench.pdf

Katz, I (2009). 'The beauty of 10:10 is that it's both achievable and meaningful', Guardian, 1 September 2009.

Kellner, D. (1995). Media Culture: Cultural Studies, Identity and Politics between the Modern and the Postmodern. London: Routledge.

Krosnick, J., Holbrook, A. and Visser, P. (2000). 'The Impact of the Fall 1997 Debate about Global Warming on American Public Opinion', Public Understanding of Science 9(3): 239-60.

Lahsen, M. (2005). 'Technocracy, Democracy, and U.S. Climate Politics: The Need for Demarcations', Science, Technology, \& Human Values 30(1): 137-69.

Latour, B. (1987). Science in Action: How to Follow Scientists and Engineers through Society. Cambridge, MA: Harvard University Press.

Linder, S.H. (2006). 'Cashing-in on risk claims: on the for-profit inversion of signifiers for "global warming"', Social Semiotics 16 (1) 103-132.

Lull, J. (1995). Media, Communication, Culture: A Global Approach. Cambridge: Polity.

McComas, K. and Shanahan, J. (1999). 'Telling Stories about Global Climate Change: Measuring the Impact of Narratives on
Issue Cycles', Communication Research 26(1): 30-57.

McCright, A. and Dunlap, R. (2000). 'Challenging Global Warming as a Social Problem: An Analysis of the Conservative Movement's Counter-claims', Social Problems 47(4): 499-522.

McCright, A. and Dunlap, R. (2003). 'Defeating Kyoto: The Conservative Movement's Impact on U.S. Climate Change Policy', Social Problems 50(3): 348-73.

McGarvey (2007). $3 x 1$ Public Relations Presentation. University of Stirling.

Moser and Dilling (2007). Creating a Climate for Change: Communicating Climate Change and Facilitating Social Change. Cambridge: University of Cambridge Press.

Nelkin, D. (1987). Selling Science: How the Press Covers Science and Technology. New York: W.H. Freeman.

Nelkin, D. (1991). 'Why is Science Writing so Uncritical of Science?', in L. Wilkins and P. Patterson (eds) Risky Business: Communicating Issues of Science, Risk and Public Policy, pp. ix-xiii. New York: Greenwood Press.

Rezwanul I,. Waliur R. Ali Gul, F. (2017). 'Savar Building Collapse. The Dark History of Dhaka Banglades!' in International Journal for Research in Business, Management and Accounting. Volume 3, Issue 2.

Schlesinger, P. (1991). Media, State, and Nation: Political Violence and Collective Identities. London: Sage.

Schlesinger, P. (1992). Europeanness: a new cultural battlefield? Innovation, 5(1).

Schwarz, M. and Thompson, M. (1990) Divided We Stand: Redefining Politics, Technology and Social Choice. Hemel Hempstead: Harvester Wheatsheaf.

Segnit, N. and Ereaut, G. (2007). Warm Words II: how the climate change story is evolving. London: IPPR/Energy Savings Trust.

Seliger, M. (1977). The Marxist Conception of Ideology: A Critical Essay. Cambridge: Cambridge University Press.

Shackley, S. and Wynne, B. (1995). 'Global Climate Change: The Mutual Construction of an Emergent Science-Policy Domain', Science and Public Policy 22: 218-30.

mith, A. D. (1991). National Identity. Harmondsworth: Penguin. 
Sorice, M. (2009). Sociologia dei Media. Rome. Stern Review (2006) The Economics of Climate Change. Cambridge: Cambridge University Press.

Szerszynski, B. and Toogood, M. (2000). ‘Global Citizenship, the Environment and the Media', in S. Allan, B. Adam and C. Carter (eds) Environmental Risks and the Media, pp. 218-28. London and New York: Routledge.

Tench, R. and Yeomans, L. (Eds) (2006). Exploring Public Relations. Harlow: Pearson Education.

Thorpe, V. (2014). 'Vivienne Westwood: climate change, not fashion, is now my priority', in the Guardian, $8^{\text {th }}$ February.

Trumbo, C. (1996). 'Constructing Climate Change: Claims and Frames in US News Coverage of an Environmental Issue', Public Understanding of Science 5: 269-73.

Trumbo, C.W. and Shanahan, J. (2000). 'Social research on climate change: where we have been, where we are, and where we might go', Public Understanding of Science 9 (2000) 199-204.

Weingart, P., Engels, A. and Pansegrau, P. (2000). 'Risks of Communication: Discourses on Climate Change in Science, Politics, and the Mass Media', Public Understanding of Science 9: 261-83.

Westwood, V. (2016). Get a Life: The Diaries of Vivienne Westwood. London: Serpent's Tail.

Wilkins, L. (1993). 'Between Facts and Values: Print Media Coverage of the Greenhouse Effect, 1987-1990', Public Understanding of Science 2(1): 71-84.

Wilson, K. (1995). 'Mass Media as Sources of Global Warming Knowledge', Mass Communication Review, 22(1-2): 75-89.'

Yerra, K. (2014). Formation of the Bengali Nationalist during the Swadeshi Movement. Amazon Kindle Edition.

Zehr, S. (2000). 'Public Representations of Scientific Uncertainty about Global Climate Change', Public Understanding of Scienc, e 9: 85-103. 
